\title{
Cutaneous granulomatosis and combined immunodeficiency revealing Ataxia-Telangiectasia: a case report
}

\author{
Laura Folgori ${ }^{*}$, Alessia Scarselli ${ }^{1}$, Giulia Angelino ${ }^{1}$, Francesca Ferrari ${ }^{2}$, Antonio Antoccia $^{3}$, Luciana Chessa ${ }^{2}$, \\ Andrea Finocchi ${ }^{1}$
}

\begin{abstract}
Ataxia-telangiectasia $(\mathrm{A}-\mathrm{T})$ is a complex multisystem disorder characterized by progressive neurological impairment, variable immunodeficiency and oculo-cutaneous telangiectasia. A-T is a member of chromosomal breakage syndromes and it is caused by a mutation in the ataxia-telangiectasia mutated (ATM) gene. Because of a wide clinical heterogeneity, A-T is often difficult to diagnose in children.

We report an unusual case of a 3-year-old boy affected by A-T who presented exclusively with extensive cutaneous granulomatosis and severe combined immunodeficiency, without neurological abnormalities, at the time of diagnosis. This case clearly emphasizes the variable presentation of A-T syndrome and highlights the difficulties in the early diagnosis of A-T.

A-T should be considered in children with evidence of combined humoral and cellular immunodeficiency associated with unexplained skin granulomatous lesions, even in the absence of the classic features of this syndrome.
\end{abstract}

\section{Introduction}

Ataxia-telangiectasia $(\mathrm{A}-\mathrm{T})$ is an autosomal recessive genomic instability syndrome characterized by progressive cerebellar ataxia, oculo-cutaneous telangiectasia, increased radiosensibility, predisposition to lymphoid malignancies and a variable degree of immunodeficiency. The prevalence is estimated to be between 1:100.000 [1] and 1:40.000 [2]. Both males and females are equally affected.

A- $\mathrm{T}$ results from mutations of a single gene, ATM (ataxia-telangiectasia mutated), located on chromosome 11q22-23 [3,4], encoding a large basic protein involved in cell cycle control and DNA damaging repair.

The diagnosis of A-T is based primarily on clinical findings. Determination of serum alpha-fetoprotein $(\alpha F P)$ is an important diagnostic marker as raised $\alpha F P$ level is found in more than $90 \%$ of A-T patients. Confirmatory tests for A-T include colony radiosensitivity assay and identification of the ATM protein by immunoblotting $[2,5,6]$.

We report the case of a 3-year-old boy affected by A$\mathrm{T}$ who presented exclusively with extensive cutaneous

\footnotetext{
* Correspondence: laura.folgori@gmail.com

'DPUO, Department of Pediatrics-University of Rome Tor Vergata/Children's Hospital Bambino Gesù, Rome
}

granulomatousis and severe combined immunodeficiency, without neurological abnormalities.

\section{Case Report}

A 3-year-old boy was referred to our Department of Pediatrics with a history of cutaneous lesions, recurrent otitis, repeated episodes of fever of unknown origin and suspected immunodeficiency. He was born full term as the second child of healthy non consanguineous parents.

At the age of 2, the child had chickenpox without complications except for a residual erythematous, scaly dermatitis characterized by small, red and indured lesions on face, arms and legs [Fig. 1]. In the suspect of hypersensitivity to insect bites, he was treated with topical treatment (steroids and tacrolimus) and oral antihistamines without improvements.

Our first clinical examination revealed a failure to thrive below the third percentile for height and below the tenth for weight. Chest $\mathrm{x}$-ray showed a lobar pneumonia. Neurological development was normal. Complete blood count (CBC) revealed lymphopenia (range 840920/ml). Quantitative Polymerase Chain Reaction (PCR) for EBV showed a massive proliferation $(1.600 .000$ 
Table 1 Immunological data

\begin{tabular}{lcc}
\hline \multicolumn{1}{c}{ Parameter } & Results & $\begin{array}{c}\text { Age matched } \\
\text { controls }\end{array}$ \\
\hline $\mathrm{WBC} / \mathrm{ml}$ & 5.700 & $5-16 \times 10^{3}$ \\
$\mathrm{Hb} \mathrm{gr/dl}$ & 12 & $11.5-13$ \\
$\mathrm{Plts} / \mathrm{ml}$ & 370.000 & $250-550 \times 10$ \\
& & \\
Serum immunoglobulin mg/dl & & \\
$\lg \mathrm{A}$ & 10 & $27-173$ \\
$\lg \mathrm{M}$ & 61 & $62-257$ \\
$\lg \mathrm{g}$ & 293 & $462-1710$ \\
$\lg \mathrm{g} 1$ & 287 & $280-830$ \\
$\lg \mathrm{g} 2$ & 9 & $40-240$ \\
$\lg \mathrm{g} 3$ & 2.4 & $6-130$ \\
$\lg \mathrm{g} 4$ & 0.3 & $3-120$
\end{tabular}

Lymphocyte phenotype

Absolute count $/ \mathrm{ml}$

CD3

CD4

CD4RA

CD4RO

CD8

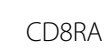

CD8RO

CD19

CD16-56

TRECS

CD4

CD8

$\begin{array}{cc}840 & 1.7-6.9 \times 10^{3} \\ 304(36.3 \%) & 0.9-4.5 \times 10^{3} \\ 121(14 \%) & 0.5-2.4 \times 10^{3} \\ 22 \% & \\ 78 \% & \\ 153(18.3 \%) & 0.3-1.6 \times 10^{3} \\ 29 \% & \\ 71 \% & \\ 42(4.9 \%) & 0.2-2.1 \times 10^{3} \\ 467(55.7 \%) & 0.1-1 \times 10^{3} \\ & \\ \text { absent } & 1.106-15.787 \\ \text { absent } & 1.106-15.787\end{array}$

Figure 1 Cutaneous granulomatous lesions. Erythematous, scaly dermatitis characterized by small, red and indured lesions on face, arms and legs.

copies $/ \mathrm{ml}$ on blood; 1.000 .000 copies $/ \mathrm{ml}$ on serum) and serological evaluation showed the absence of anti-EBNA IgG. Immunological work-up revealed a combined immunodeficiency [Tab. 1, 2]. Serum IgG and IgA levels were low for the age, as well as IgG2 and IgG4. Specific antibodies response against tetanus toxoid and $\mathrm{HiB}$ was low, whereas titer versus Pneumococcal antigens was undetectable despite of three vaccine doses performed. Peripheral blood lymphocyte subsets repeatedly showed a markedly reduced levels of both $\mathrm{T}$ and $\mathrm{B}$ cells; distribution of naïve and memory $\mathrm{T}$ cells showed a marked predominance of $\mathrm{T}$ cells with a memory phenotype $(\mathrm{CD} 4+\mathrm{CD} 45+\mathrm{RO}+\mathrm{CD} 8+\mathrm{CD} 45+\mathrm{RO}+)$ and a corresponding reduction of naïve T cells; HLA class I and II expression on lymphocytes was normal. NK cells were very increased (48\%) with normal NK activity. Lymphocyte proliferative response to antigens and mitogens was normal, except for a diminished response to PMA + IONO. Thymic output, evaluated by measuring T-cell

\section{Response to mitogens and}

antigens (counts per minute)

\begin{tabular}{lcc} 
none & 439 & $>430$ \\
PHA & 33775 & $>35000$ \\
OKT3 & 34410 & $>25000$ \\
PMA+IONO & 4772 & $>25000$ \\
none & 3069 & $>1250$ \\
Candida & 9711 & $>5000$ \\
Tetanus toxoid & 3231 & $>5000$ \\
\hline
\end{tabular}

Table 2 Serological data after 3 vaccine doses

\begin{tabular}{lcc}
\hline \multicolumn{1}{c}{ Parameter } & Results & Reading \\
\hline Tetanus toxoid IU/ml & 0.1 & $>0.1 \mathrm{IU} / \mathrm{ml}$ \\
Haemophilus influenzae B mg/l & 0.1 & $>1 \mu \mathrm{g} / \mathrm{ml}$ \\
S. Pneumoniae $\mathrm{mg} / \mathrm{l}$ & 3 & $>20 \mathrm{mg} / \mathrm{l}$ \\
\hline
\end{tabular}

receptor (TCR) rearrangement excision circles was extremely low in both CD4+ and CD8+ T cells. Analysis of TCR by CDR3 spectratyping revealed oligoclonal expansion in the most of peripheral CD8+ and CD4+ T cells. Skin biopsy showed granulomatous inflammation with an infiltrate characterized by polymorphic lymphocyte and 
epithelioid cells; Periodic acid-Schiff (PAS), Giemsa, and Ziehl-Neelsen staining of skin-biopsy specimens showed no evidence of fungi or mycobacteria and PCR assays for mycobacterium tuberculosis were negative. In situ analysis of TCR repertoire of CD3 lymphocyte resulted completely skewed.

Intravenous immunoglobulin infusion at the dosage of $400 \mathrm{mg} / \mathrm{Kg}$ monthly and prophylactic treatment with trimethoprim-sulfamethoxazole was started; during this period a marked reduction of EBV viral load was observed. Six months later the child experienced a bilateral acute otitis that required a long and multiple antibiotic therapy.

Based on the male-gender, hypogammaglobulinemia and high EBV replication rate, we firstly ruled out Lymphoproliferative X-linked Syndrome (XLP) and XIAP deficiency by molecular analysis [7]. Schuetz et al. reported a hypomorphic heterozygous RAG mutation with skin granulomatous lesions associated with secondary complications of EBV infection and severe immunological abnormalities [8]; molecular analysis for RAG1/2 resulted negative. Even in the absence of a severe clinical picture, immunological $\mathrm{B}$ and $\mathrm{T}$ cells alterations led us to consider a leaky SCID. Sequencing of common $\gamma$ chain and IL7-R genes and dosage of ADA enzyme in white blood cells and plasma resulted normal. There was no evidence of maternal engraftment in the patient's peripheral blood by chimerism analysis.

In the suspect of a double strands break repair defect, radiosensitivity test was performed, showing an increased number of chromosomal aberrations. Alphafetoprotein $(\alpha F P)$ serum value repeatedly resulted increased (135 ng/ml, n.v. $<10 \mathrm{ng} / \mathrm{ml})$ and Western Blotting showed the absence of ATM protein.

Characterization of the ATM gene mutations are in progress.

Phenotypic heterogeneity has long been identified in both laboratory and clinical features of A-T, ranging from the classic form with typical symptoms to unusual disease presentation. Neurological involvement (i.e. cerebellar ataxia and dysarthria) and ocular telangectasia are the hallmarks of A-T. Nevertheless, milder forms of A-T, which are characterized by late onset or slow progression of neuromotor dysfunction, have been described and diagnosed even among adults during evaluation on unknown ataxia. The typical cutaneous manifestation of the disease is ocular telangectasia although some patients have no telangectasia, even in adulthood; cutaneous granulomatosis with no identifiable infectious origin occurs rarely in children with primary immunodeficiency [8-10]. These cutaneous granulomas have been previously described in common variable immunodeficiency [9,11-13], chronic granulomatous disease, $\mathrm{X}$-linked hypogammaglobulinemia $[14,15]$ but rarely in A-T [16-19]. Furthermore, we did not see resolution of granulomas after neither the local immunosuppressive therapy, nor the treatment with intravenous immunoglobulin, as it has been reported in some patients with common variable immunodeficiency $[9,20,21]$.

Similarly to the phenotypic features, a wide variability of immunological defects exists in patients with A-T syndrome, ranging from the absence of immune defects to severe immunodeficiency with recurrent infections $[22,23]$. Low levels of IgG, IgA and IgE are observed in more than $80 \%$ of the patients, whereas severe combined immunodeficiency with recurrent infections occur rarely. In our patient, immunological abnormalities were so severe that led us to suspect a combined immunodeficiency. Diagnosis led us to reveal A-T even in child's elder sister (8-years-old) for whom a wrong spastic paresis diagnosis was previously made elsewhere. She conversely presented a common clinical phenotype of A-T, showing progressive neurological degeneration with ataxia, dysarthria, dyskinesia, dystonia and oculo-cutaneous telangiectasia. Her immunological work-up only revealed a mild lymphopenia with an IgA defect. The different clinical picture seen in patients with defects of that same gene can be caused by specific mutations, other genetic factors or epigenetic mechanism. Previous studies have failed to indicate a specific correlation between the amount of ATM protein and radiosensitivity. However, the results of various studies suggest a clear correlation between preservation of neurological function, decreased radiosensitivity and level of normal ATM protein kinase activity. Interestingly, there are siblings, as our patients, who reported absent ATM protein but clinically and laboratory distinct phenotypes $[23,24]$. Thus, our case supports the lack of a strict genotype-phenotype correlation[2,22-26] suggesting that the heterogeneity of A-T is much broader than initially recognized and that $A-T$ represents a complex spectrum of the disease shaped by the genetic mutations, host characteristics, pathogens (EBV) and environmental factors.

The prevalence of the disease reported in the literature is very variable and estimated to be $1: 40,000-100,000$ births $[1,2]$; this is probably due to the wide clinical heterogeneity that often leads physicians to an incorrect or missed diagnosis. Atypical presentation of our patient caused a delay of diagnosis; there should be a high index of suspect for A-T among children with recurrent infections and immunodeficiency, even in the absence of neurological abnormalities. Accordingly, screening with serum alpha-fetoprotein, a simple, rapid and reliable test for A-T, should be part of the evaluation of children with any congenital immunodeficiency. A delayed diagnosis can often affect the clinical evolution and influence the management of A-T patients and their relatives [1,27]. Early diagnosis alerts the physicians to limit ionizing radiations exposure, including the diagnostic methods. Also, early diagnosis 
allows genetic counseling as well as the identification of the carrier parents who may have an increased cancer risk, particularly breast cancer in women $[1,28]$.

\section{Conclusion}

In conclusion, $\mathrm{A}-\mathrm{T}$ syndrome should be considered in children with an evidence of combined humoral and cellular immunodeficiency and otherwise unexplained granulomatous skin lesions.

\section{Consent}

Written informed consent was obtained from the patient's relatives for publication of this case report.

\section{Acknowledgements}

Prof. Paolo Rossi for critically review in the manuscript.

\section{Author details}

'DPUO, Department of Pediatrics-University of Rome Tor Vergata/Children's Hospital Bambino Gesù, Rome. "ll School of Medicine, University "Sapienza", Rome. ${ }^{3}$ Department of Biology, University Roma Tre, Roma.

\section{Authors' contributions}

LF and AS were involved in clinical care of patient and contributed to the writing of the paper. GA were involved in clinical care and in the collection of clinical data of the patient. LC and FF performed Western Blot analysis. AA performed the Radiosensitivity Test. AF has defined the clinical picture of the patient, formulated diagnosis and wrote the paper. All authors have read and approved the final manuscript.

\section{Competing interests}

The authors declare that they have no competing interests.

Received: 25 February 2010 Accepted: 11 April 2010

Published: 11 April 2010

\section{References}

1. Cabana MD, Crawford TO, Winkelstein JA, Christensen JR, Lederman HM: Consequences of the delayed diagnosis of ataxia-telangiectasia. Pediatrics 1998, 102:98-100.

2. Chun HH, Gatti RA: Ataxia-telangiectasia, an evolving phenotype. DNA Repair (Amst) 2004, 3(8-9):1187-96.

3. Lange E, Borresen AL, Chen X, Chessa L, Chiplunkar S, Concannon P, Dandekar S, Gerken S, Lange K, Liang T, et al: Localization of an ataxiatelangiectasia gene to an approximately 500-kb interval on chromosome 11q23.1: linkage analysis of 176 families by an international consortium. Am J Hum Genet 1995, 57(1):112-9.

4. Gatti RA, Berkel I, Boder E, Braedt G, Charmley P, Concannon P, Ersoy F, Foroud $T$, Jaspers NG, Lange $K$, et al: Localization of an ataxiatelangiectasia gene to chromosome 11q22-23. Nature 1988, 336(6199):577-80.

5. Perlman S, Becker-Catania S, Gatti RA: Ataxia-telangiectasia: diagnosis and treatment. Semin Pediatr Neurol 2003, 10(3):173-82.

6. Chun HH, Sun X, Nahas SA, Teraoka S, Lai CH, Concannon P, Gatti RA: Improved diagnostic testing for ataxia-telangiectasia by immunoblotting of nuclear lysates for ATM protein expression. Mol Genet Metab 2003, 80(4):437-43.

7. Rigaud $S$, Fondanèche $M C$, Lambert $N$, Pasquier $B$, Mateo $V$, Soulas $P$, Galicier L, Le Deist F, Rieux-Laucat F, Revy P, Fischer A, de Saint Basile G, Latour S: XIAP deficiency in humans causes an X-linked lymphoproliferative syndrome. Nature 2006, 444(7115):110-4.

8. Schuetz C, Huck K, Gudowius S, Megahed M, Feyen O, Hubner B, Schneider DT, Manfras B, Pannicke U, Willemze R, Knüchel R, Göbel U, Schulz A, Borkhardt A, Friedrich W, Schwarz K, Niehues T: An immunodeficiency disease with RAG mutations and granulomas. $N$ Engl J Med 2008, 358(19):2030-8.
9. Mitra A, Pollock B, Gooi J, Darling JC, Boon A, Newton-Bishop JA: Cutaneous granulomas associated with primary immunodeficiency disorders. Br J Dermatol 2005, 153(1):194-9.

10. Gallerani I, Innocenti DD, Coronella G, Berti S, Amato L, Moretti S, Fabbri P. Cutaneous sarcoid-like granulomas in a patient with X-linked hyper-lgM syndrome. Pediatr Dermatol 2004, 21(1):39-43.

11. Lin JH, Liebhaber M, Roberts RL, Dyer Z, Stiehm ER: Etanercept treatment of cutaneous granulomas in common variable immunodeficiency. J Allergy Clin Immunol 2006, 117(4):878-82.

12. Abdel-Naser MB, Wollina U, El Hefnawi MA, Habib MA, El Okby M: Nonsarcoidal, non-tuberculoid granuloma in common variable immunodeficiency. J Drugs Dermatol 2006, 5(4):370-2.

13. Malphettes M, Oksenhendler E, Galicier L, Fieschi C: Granulomatous disease in common variable immunodeficiency. Rev Med Interne 2008, 29(1):28-32.

14. Vergnon JM, Guichenez P, Oriol P, Poulard G, Jaubert J, Emonot A: Acquired hypogammaglobulinemia and multifocal granulomatosis. Rev Mal Respir 1993, 10(5):480-2.

15. Fleming MG, Gewurz AT, Pearson RW: Caseating cutaneous granulomas in a patient with X-linked infantile hypogammaglobulinemia. J Am Acad Dermatol 1991, 24(4):629-33.

16. Paller AS, Massey RB, Curtis MA, Pelachyk JM, Dombrowski HC, Leickly FE, Swift M: Cutaneous granulomatous lesions in patients with ataxiatelangiectasia. J Pediatr 1991, 119(6):917-22.

17. Drolet BA, Drolet B, Zvulunov A, Jacobsen R, Troy J, Esterly NB: Cutaneous granulomas as a presenting sign in ataxia-telangiectasia. Dermatology 1997, 194(3):273-5.

18. Joshi RK, al Asiri RH, Haleem A, Abanmi A, Patel CK: Cutaneous granuloma with ataxia telangiectasia-a case report and review of literature. Clin Exp Dermatol 1993, 18(5):458-61.

19. Corbisier A, Eschard C, Motte J, Munzer M, Barhoum K, Kalis B, Grosshans E: Cutaneous granulomatous lesions disclosing ataxia-telangiectasia. Ann Dermatol Venereol 1999, 126(8-9):608-11.

20. Alvarez-Cuesta C, Molinos L, Cascante JA, Soler T, Pérez-Oliva N: Cutaneous granulomas in a patient with common variable immunodeficiency. Acta Derm Venereol 1999, 79(4):334.

21. Cornejo P, Romero A, López S, Guerra A, Gil R, Iglesias L: Cutaneous and hepatic granulomas in a young woman with common variable immunodeficiency. Br J Dermatol 1999, 140(3):546-7.

22. Claret Teruel G, Giner Muñoz MT, Plaza Martín AM, Martín Mateos MA, Piquer Gibert M, Sierra Martínez Jl: Variability of immunodeficiency associated with ataxia telangiectasia and clinical evolution in 12 affected patients. Pediatr Allergy Immunol 2005, 16(7):615-8.

23. Soresina A, Meini A, Lougaris V, Cattaneo G, Pellegrino S, Piane M, Darra F, Plebani A: Different clinical and immunological presentation of ataxiatelangiectasia within the same family. Neuropediatrics 2008, 39(1):43-5.

24. Morio T, Takahashi N, Watanabe F, Honda F, Sato M, Takagi M, Imadome Kl, Miyawaki T, Delia D, Nakamura K, Gatti RA, Mizutani S: Phenotypic variations between affected siblings with ataxia-telangiectasia: ataxiatelangiectasia in Japan. Int J Hematol 2009, 90(4):455-62.

25. Becker-Catania SG, Chen G, Hwang MJ, Wang Z, Sun X, Sanal O, Bernatowska-Matuszkiewicz E, Chessa L, Lee EY, Gatti RA: Ataxiatelangiectasia: phenotype/genotype studies of ATM protein expression, mutations, and radiosensitivity. Mol Genet Metab 2000, 70(2):122-33.

26. Gilad S, Chessa L, Khosravi R, Russell P, Galanty Y, Piane M, Gatti RA, Jorgensen TJ, Shiloh Y, Bar-Shira A: Genotype-phenotype relationships in ataxia-telangiectasia and variants. Am J Hum Genet 1998, 62(3):551-61.

27. Crawford TO, Skolasky RL, Fernandez R, Rosquist KJ, Lederman HM: Survival probability in ataxia telangiectasia. Arch Dis Child 2006, 91(7):610-1.

28. Swift M, Morrell D, Massey RB, Chase CL: Incidence of cancer in 161 families affected by ataxia-telangiectasia. N Engl J Med 1991, 325(26):1831-6.

doi:10.1186/1824-7288-36-29

Cite this article as: Folgori et al:: Cutaneous granulomatosis and combined immunodeficiency revealing Ataxia-Telangiectasia: a case report. Italian Journal of Pediatrics 2010 36:29. 